\title{
MAP3K5 Gene
}

National Cancer Institute

\section{Source}

National Cancer Institute. MAP3K5 Gene. NCI Thesaurus. Code C106620.

This gene is involved in the MAP kinase signal transduction pathway. 